\begin{tabular}{l|l|l|l|l}
\hline Volume 2 & Issue 1 & April (2021) & DOI: 10.47540/ijsei.v2i1.101 & Page: $22-30$ \\
\hline
\end{tabular}

\title{
Child Fostering or Child Trafficking: Questioning Justifications for Children's Departure from Home
}

\author{
Ifeyinwa Mbakogu \\ School of Social Work Dalhousie University, Canada
}

Corresponding Author: Ifeyinwa Mbakogu; Email: ifeyinwa.mbakogu@dal.ca

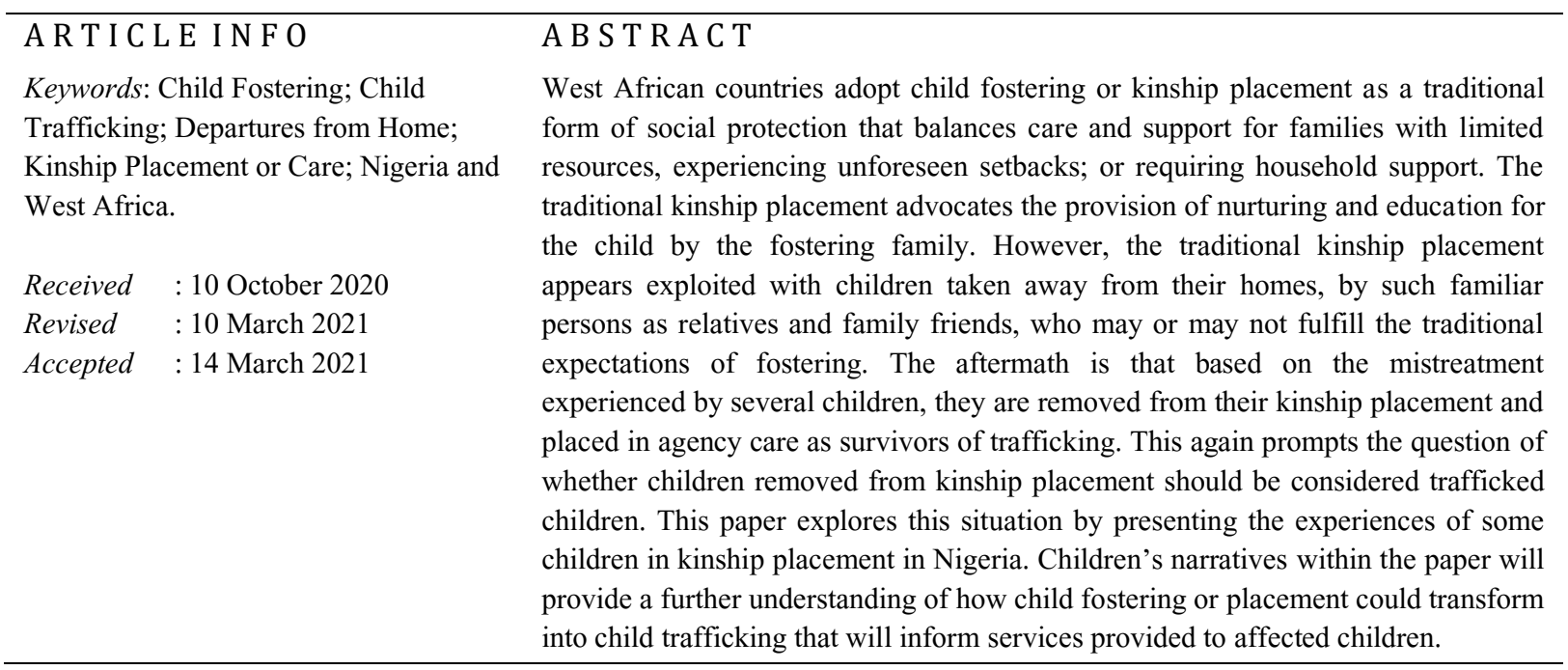

\section{INTRODUCTION}

The Confusion between Child Trafficking and Child Fostering: Child placement or fostering appears to have deviated from its initial supportive traditional conceptualization in West African countries to become a template for the new trafficking in the 21st Century. Moreover, since: “... sustainable development is ... an attempt by countries to meet the welfare and survival needs of their citizenry, the high incidence of trafficking in children..." (Mbakogu, 2016, p. 48) is likely to impede attaining this goal and should be a crucial area of focus. It is essential to understand how fostering is projected in the literature and research to ask if all fostering should be considered bad. A recurrent tension in the literature on child trafficking in West Africa is that child trafficking is increasingly attributed to the age-old African practice of child fostering or placement. Here, the paper will dwell on the meaning of child fostering, types of fostering, child fostering's association with trafficking, and the implications for the persistence of fostering practices.
The idea of child fostering originates from the role of the extended family system in African countries as a recognized social institution (Case, Paxson, \& Ableidinger, 2004; Desai 1995; IsiugoAbanihe, 1985; Zimmerman, 2003) or a traditional social security system (Foster, 2000) that contributes to the wellbeing of children. Within the extended family system, a child is seen as the responsibility of the entire community or clan, thereby allowing parenting roles or child-rearing costs to be shared (Bledsoe, 1990; Goody, 1982). This sharing is done with relatives, siblings, parents, and more recently, close family friends.

Child fostering also has a socialization mission (Isiugo-Abaribe, 1985; Uzodike, 1990) that is built on the community practice of sending children to live with a relative who is expected to provide good training either in a trade or, with modernization, to enroll children in formal schools (Gale, 2008). Serra (2008) adds a more exhaustive list of the reasons for fostering in West Africa as: “... strengthening extended family ties, redistributing child labor, making life-cycle adjustments of household size and 
composition, schooling, and taking advantage of an informal insurance mechanism..." (p. 157). Also, when children are sent to live with relatives or friends, an arrangement could be made about nurturing costs. In some cases, foster parents may bear all or a majority of the day-to-day costs while parents bear some of the educational costs (Bledsoe \& Isiugo-Abaribe, 1989; Gale 2008).

There are different ways of looking at fostering. It could be looked at in terms of who is involved and for what reason. Isiugo-Abaribe (1985) presents the intricate and complex nature of fostering thus: ...unique to West African fostering are both its prevalence and the very early age at which children are boarded out. Furthermore, because fostering here is rooted in kinship structures and traditions, children are sent out not only in the event of a family crisis or when one or both natural parents cannot, for some reason, manage to bring them up. Rather, the sending out of children is practiced by both stable and unstable families, married and single mothers, healthy and handicapped parents, rural and urban homes, and wealthy and poor parents (p. 56)

Under the traditional practice of fostering, anyone could foster a child because it was a way of providing communal assistance to any member of the kindred considered in need. This person(s) could be a childless woman or young couple with toddlers, requiring a live-in companion or household assistance; or someone requiring support in caring for an elderly parent. Within the cultural practice of fostering, there was no limit to the reach of assistance kinsmen provided to each other (Mbakogu, 2004, 2015). Isiugo-Abaribe (1985) points out that fostering could also be equated with the migratory activities of parents in West Africa especially when they are trying to return to the labor force, school, or migrate to new locations, within or outside their country of origin. To meet these goals, parents explore fostering to offset the constraints of caring for or thinking about the wellbeing of their children.

So how can fostering go bad? Sometimes parents may innocently be sending their children to live with a close relative for reasons ranging from economic, moral to educational (Bass, 2004). This practice of child placement is not prohibited. It is expected that since the fostered child is often a close relative, they will be treated as a member of the fostering household. But parents can never be certain that their relatives will not maltreat their children. In extreme cases, relatives may exploit the traditional fostering practices to hand children entrusted to them over to traffickers who engage them in forced labor (Mbakogu, 2016; Pilon, 2003). The trafficker in contemporary times could be a close relative, parent, or sibling. However, when people taking children away from home make insincere promises about reciprocity and return after children have lived and worked with them, then what can be an innocent, often beneficial cultural practice becomes an exploitative act (Manzo, 2005; Mbakogu, 2015).

It would be next to impossible for governments or anti-trafficking agencies to prevent parents from handing over their children to live with close relatives or screen all fostering for bad situations. In the first place, parents would find it difficult to accept from a cultural point of view, that their 'blood relative' would harm their child when placed to live with them. Second, parents always have a purpose when sending their children out to be fostered by other people (Case et al., 2004; Gale 2008). The incentive for moving children away from home and getting parental consent for this movement in some cases originates from parental inadequacy and the option of providing alternatives for the child's wellbeing in a new location. These parental constraints leading to consent for their children's movement from home could be poverty, lack of access to competitive school facilities, or lack of monetary investment to learn a trade or start a new vocation. In the traditional sense of fostering, parental inadequacy is not necessarily a factor, because the incentive for children's movement away from home rests on growth and learning which could be moral, economic, religious, cultural, social, or educational - that is best achieved away from the natural home (Goody, 1982; Gould, 1985; Mbakogu, 2004, 2015).

The literature also attests to the potential implications of fostering. For instance, with wars or conflict situations in several African countries, there has been a rise in the number of displaced and orphaned children requiring fostering, causing a strain on the extended family system (Boyden \& Mann, 2007; Foster, 2000). Some findings reveal that when children are fostered as a result of the death of a parent or disruptions in the household, 
they are likely to experience interruptions in their education and have a lot more duties in the fostering household (Ainsworth et al., 2005; Mbakogu, 2015, 2020). This is unlike children who are fostered based on mutual agreement between the child's parents and the fostering relative or household.

Within the cultural formulation of fostering, there are good intentions for sending children out to live with persons who are not their parents. When the goals intended by the fostering arrangement are achieved then it is considered good fostering. But fostering is considered bad and may be linked to trafficking when the entire traditional arrangement of socialization is corrupted by people exploiting children and the services that they (children) are expected to provide. According to Isiugo-Abaribe (1985), parents should not see themselves as inferior for allowing their children to be fostered, for the fostered child could return to the community several years later as "....an important source of wealth transfer to the parents, or of social mobility for the clan or kin group" (p.71). There are many situations where fostered children have enjoyed the benefit of education, vocational skills, simply by moving away from home, and according to Howard (2011), some fostered children maintain good relationships with their employers or foster parents.

This paper is shaped by the experiences of children in kinship placement from a larger study of children removed from diverse forms of trafficking in West Africa. The paper discusses the findings of the study with links to related literature on the confusion between trafficking and fostering. The paper hopes to contribute to empirical literature for understanding why and how children are leaving home; and the formulation of interventions for reintegrating children after they are removed from trafficking. The paper is informed by these questions: (1) What is the perception of children in kinship placement about their movement away from home? (2) When do children perceive their experience in kinship placement as good or bad? (3) Should children exploited and removed from kinship placement be considered trafficked children?

\section{Materials AND Methods}

Children's narratives presented in this article are taken from a larger study conducted in Nigeria for the researcher's doctoral thesis. The study engaged with about 70 West African children under the age of 18 years removed from diverse forms of trafficking by personnel of Nigerian's antitrafficking agency, the National Agency for the Prohibition of Traffic in Persons and other related Matters (NAPTIP), and residents in some of their shelters in different zones (Lagos, Enugu, Akwa Ibom, Abuja, and Edo), in Nigeria. The paper projects the narratives of child participants who left home based on kinship fostering by close relatives residents in large cities in Nigeria.

The study used different qualitative research methods including personal interviews, focus group discussions, drama, and drawings with child participants. Since children could be dealing with the trauma associated with their trafficking experiences, it was important to ensure that research was coordinated in a respectful way, by building rapport and comfort between the researcher and participating children. To foster this relationship, the researcher remained for extended periods (usually one to two months) with children in each participating shelter. The sessions with children adopted a participatory approach that put the timing and application of tools in the children's hands. The interaction with the children was directed solely by the researcher who has extensive experience working with populations dealing with trauma in multiple contexts, human trafficking included. The study commenced after Ethics approval was received from McGill University's Human Ethics Board. The research and its intent were explained to participating children. Consent forms for children's participation in the study were also signed by NAPTIP officials. Notwithstanding, the final assent to participate in the study was given by the children themselves.

The personal interviews with each participating child lasted from 30 minutes to an hour. The interview sessions were audio-recorded with the consent of the respondents. To protect participant confidentiality, all child participants were assigned numbers or aliases. Children also decided the most comfortable starting point for the research interaction - while some children favored beginning with personal interviews, other children 
favored using such art-based methods as drawing or drama. Because drawing sessions with children allowed for a pictorial depiction of their trafficking experiences, several children preferred exploring it as an often less traumatic platform to share their trafficking stories. The goal of the diverse modes of engagement with children was to project children's (rather than the researcher's or agency's) voice in understanding why they left home and their experiences while away from home.

The study sought to understand children's experiences of trafficking, children's cultural expression of their journey away from home, and what these project - trafficking or fostering in children's own words. The researcher assumed the role of collector of stories told by children. These stories are analyzed using a structural analysis that allowed the researcher to tease out and express perspectives considered important to the child storyteller. These perspectives could be cultural, moral, identity, social, economic, gender, and religious based (Phoenix \& Smith, 2011). The focus is to understand how these narratives affect the participant's lives either positively or negatively. The interviews were transcribed verbatim. The interviews and the stories behind children's drawings (explained by the children themselves) were analyzed to document the codes and themes generated from the data. Certain themes building from children's narratives helped the researcher understand what fostering meant to the child moving away from home and if their journey away from home aligned with the initial goals of children and their parents. The identified themes included socialization; education; betrayal, helplessness or support, strained relationships, and distrust.

\section{RESULTS AND DISCUSSION}

Child placement practices in West Africa have remained a traditional way of providing support for child nurturing, sharing roles, supporting families in crisis, and performing communal welfare services to extended family members and more recently close family friends have been included in the supportive network. Research indicates that children in kinship placement are likely to be: children from broken homes, orphans, children from homes experiencing economic setbacks, or seeking support in acquiring educational or vocational skills (Ainsworth \& Filmer, 2006; Akresh, 2009; Isiugo-
Abaribe, 1985). Considering that several children have been exploited in the course of moving them away from home, should all kinship placement be considered bad, including those where children and their families benefit from them (Davidson, 2016). The ideal point of reference for understanding the decision-making process and experiences within and after removal from kinship placement should come from affected children themselves. The narratives of children help tease out the diverse thoughts shaping children's consciousness as they move away from home, with hopes of a better future and how their return to their old homes may be impacted by their experiences while away from home.

\section{Fostering as Socialization}

Children have been moved from their homes to that close relatives in many parts of West Africa to uphold the age-old practice of socialization or child fostering. In the traditional practice, older sisters have been known to move into their marital homes with their younger sisters as a company. Through this arrangement, the younger sister becomes a familiar face that assists her with child care and nurturing. The older sister responds by providing care, support, and finances for her younger sister's education. This practice has been bastardized in recent times with the deceptive fostering practices of relatives and other guardians (Mbakogu, 2015). Some children indicate that they have benefited from this traditional form of fostering. Odinaka, who is 17 and the seventh of 8 children, narrates how her older sister took her to live with her when she got married:

I stopped my schooling at SS2. What made me stop my schooling at SS2 was ... that time, someone raped me then ... I got pregnant... in PortHarcourt. My elder sister is living on that side. She is the one that trained me because my Dad died when we are tender. Before my Dad died, she told him that she will want me to go along with her. My Dad said no, that he does not want any of his children to be going out. She said for the sake of one thing that I will be assisting her with certain things at home. Then she brought me to PortHarcourt. I was very small, 4 years to 5 years. She now took me along. I was staying there with her.

In Odinaka's case, she benefitted from living with her older sister. Besides, Odinaka's father passed away shortly after she left home to live with 
her sister, so living with her older sister took some weight off her mother. Odinaka maintained that her older sister provided her with good education by enrolling her in good private schools in Nigeria. However, things went wrong when she was raped towards the end of her senior secondary school (SS2) program. Odinaka did not inform her older sister that she was raped until it was too late to identify and apprehend the perpetrator. Before the pregnancy became noticeable, Odinaka dropped out of school and left her sister's home in Port-Harcourt to live with her mother in the village.

\section{Fostering and Assumed Relationships}

One might expect that, similar to Odinaka's experience, a child is more likely to understand the dispositions of a close relative and feel safe when living with them. That may not apply to all fostered children. Another child participant, Eziuwa, now 14 years old, could not recall her age when her father's younger sister took her from her widower father to live with her and attend school in Lagos. Since Eziuwa was too young to remember her age on moving in with her aunt, it is obvious that she did not contribute to decisions the family made about living with her aunt. This could be linked to the gendered nature of the decision-making process informing children's movement from home. While boys in Southern Benin have a voice in asserting their preferred kinship placements, usually in wageearning kinship placements, girls likely end up in domestic kinship placement with decisions made by adults without their input (Boyden \& Howard, 2013).

Eziuwa embarked on the journey from her village to Lagos in the company of her aunt's husband (her uncle). Her aunt has four children, who Eziuwa is expected to care for while fostered by her aunt. On a typical weekday, Eziuwa says that after school she would go to her aunt's shop to assist in frying buns for sale. When the shop closed for the day, she would return home to continue her household chores until about midnight, if she was lucky, or 1:00 am. Eziuwa said that she was only sure of sleeping at reasonable hours and functioning without physical abuse when her uncle was home. Agblorti and Tanle's (2011) study, conducted in Ghana, report negative correlations between fostering and education. They found that while children living with their biological parents fare better educationally, children in fostering are unlikely to be enrolled in school and when they are enrolled, may not attend school regularly. Eziuwa recalls her last days with her aunt:

It was on Saturday when she came to the bathroom and asked me if this is how I wash toilets. I told her that I had finished washing the toilet, that I was now washing the walls. She said that I was wasting her OMO [detergent]. So, she now took the cord for the radio and starting hitting me with it until she cut my mouth. Her neighbor told her to leave me. When she left me and went to the market the neighbor then took the cell phone and snapped a picture of me. She asked me if I wanted to leave and I said yes. She said I should not worry. I think she was the one that reported to NAPTIP. The NAPTIP people came to collect me on Thursday. So, on Monday I was washing plates because I slept late the previous night and woke up around 5 am. I was washing plates and feeling sleepy. I was now sleeping in the kitchen. She saw me sleeping in the kitchen and brought a cane to flog me. I held the cane to prevent her from flogging me. She then decided to bite me with her teeth.

Eziuwa's second encounter with her aunt depicts a common aspect of discipline where children are expected to remain docile as parents or older persons punish them for wrongdoing. Children are expected to resist clutching the cane, even when they know they could be hurt or even maimed by the cane. However, it is difficult to understand why her aunt responded with a bite when Eziuwa held on to the cane. Where does socialization or assistance by an aunt towards her niece begin and end? Eziuwa expects that as her father's sister, her aunt should look out for her and understand her limitations or inability to function in her home with minimal hours of sleep. Eziuwa also expects her aunt to tell her when and how she went wrong without inflicting harm. According to Eziuwa, she cleaned the toilet the way she had always done since moving into the household and expected her aunt to explain where she went wrong or if she needed things done differently. Eziuwa was brought to the NAPTIP shelter after a neighbor called the agency to report the recurrent assault on a child by her aunt.

\section{Fostering and Uncomfortable Family Dynamics}

Another child, 15-year-old Emilia is the ninth of 11 children. Her parents, who are separated, are farmers. Her father has remarried and has other 
children from the second wife. Emilia left home to live with her father's sister when she was 4 years old and it was only when she was afflicted with a strange illness before her Junior Secondary School Certificate Examination (JSCE) that her aunt returned her home to her parents. According to Emilia, she was enrolled in school but treated with spite by her uncle and his children:

I didn't have any problem with my aunty... although I was having problems with the husband. The husband used to beat the hell out of me. The man doesn't like me. I don't know why... but he used to say that I am not part of his family... My aunty didn't make me feel uncomfortable, it's the husband that did that. The oldest son is two years older than me. The other ones, I was the one that carried them [care giver]. I was not comfortable with the children... They used to torment me that I should get out of their father's house. Their dad used to ask me 'what are you doing here, this is not your home'... But she is my dad's sister. The man used to push me ... I used to roll on the staircase and land on the floor. She knows, but anytime she wants to talk, he will beat her up...

The helplessness Emilia portrays in her narrative is also reflected in the helplessness of her aunt who, though the breadwinner of the family, had to endure the violent tendencies of an abusive husband. Though the persistent beating, pushing, and tumbling downstairs were likely to get the child maimed or killed, Emilia endured humiliation at the hands of the man and his children because remaining in her aunt's place was the only way she was sure of getting an education. It was only when she fell ill and unable to make cogent decisions about remaining in kinship placement that her aunt took her back to her parents. After recuperating, Emilia's aunt was unable to accept her into her home because she was fostering another child from her husband's family. Unlike Eziuwa, Emilia was supported by her aunt but both their lives (Emilia's and her aunt's) were made unbearable by her aunt's husband who used them as punching bags.

During the interaction with children, it was observed that their departure from home takes different forms. A common feature is an attempt to reinforce the waning child fostering practice where the child is sent to live with a close relative or friend, with the expectation that the child's care, education, and growth will be part of the socialization process. This manifests in the manner in which children like Eziuwa, Odinaka, and Emilia left home. Their narratives also warrant a closer look at the age-old cultural practice of socialization, assistance, and support to decipher where things went wrong. Ideally, the fostering practice, according to Goody (1982) is the socialization that offers training, knowledge, and additional experience to the fostered child. But these socialization goals do not belie the fact that fostering in some African countries is motivated by the receiving household's need for a young child to assist with household chores (Ainsworth, 1990). Isiugo-Abanihe (1985) presents a more detailed understanding and explanation of the conceptualization of fostering in West Africa that fits the demographics of fostered children in the study. The author attests that since fostering occurs as a traditional practice in several West African countries, children do not leave home only when their families are experiencing a crisis. Child placement practices or exchanges may occur within and across different family demographics (polygamous or single-family homes, rich and poor families) in rural and urban settings.

Some researchers attest to the positive aspects of fostering in providing the best care for children leading to adulthood especially when their biological parents are unable to do this (Bledsoe, 1990; Serra, 2009). On the other hand, with findings from their research in Ghana, Kuyini et al., (2009) draw attention to the abusive practices resulting from fostering while Pilon (2003) highlights uncertain findings concerning school attendance for fostered children. If socialization was the reason for children's movement from home then there would be no reason for children to run away, because education, which is the supposed purpose of child fostering, involves a mutual process of communication, seeking clarification, and establishing learning between the child, the immediate family, and the older relative.

The findings also show that children, fostered by blood relatives, are more likely to attend school than other trafficked children. However, with excessive household tasks children may be prone to fatigue, resulting in unsatisfactory school performance and irregular school attendance records (Mbakogu, 2015). Even when the foster parents are close relatives, they are more likely to 
send the fostered child on excessive errands than their own children (Ainsworth, 1992; Howard, 2011; Mbakogu, 2016). Another study reports that children preferred to be fostered by their grandparents rather than their uncles or aunts who may only accept them into their household out of a sense of obligation rather than assurance of providing love and care (Kuyini et al., 2009). It appears that exploitation of those considered helpless has become so ingrained in the postcolonial period that Goździak's study with 30 child survivors of trafficking from four continents (2008) reports that extended family members did not consider the treatment of children in their care to be exploitative or wrong. Furthermore, there is the suggestion that parents like Eziuwa's father, who send their children to remain in the care of relatives, do not understand the new dangers of unimagined exploitation that children may face while engaged in the old practice of fostering (UNICEF, 2002).

It is essential to recognize who is trafficked and who is not trafficked within the context of interventions or services provided by agencies, such as NAPTIP to affected children. Should children that are fostered by close relatives fall into the category of trafficked children? It could be argued that the children were moving away from home backed by parental consent and within the context of the age-old practice of kinship fostering, which some of their parents experienced at a similar age. Parents could argue that they also left home as children for various reasons - to earn an income, learn skills that prepare them for a future profession, learn new skills to become good wives in the future, assist relatives with household chores, or access educational opportunities in the city.

In the agency's defense, NAPTIP's role is to protect children from all forms of exploitative practices in the course of their movement away from home. With reference to 14-year-old Eziuwa who was fostered by her aunt, her narratives indicate that she endured several abusive acts while in residency. The abuse became so traumatic that neighbors made a call to NAPTIP, leading to Eziuwa's removal from her aunt's home. But what does Eziuwa say about her fostering? Does she blame her father for sending her away to be fostered or her aunt for the maltreatment she experienced? No. Eziuwa was certain that her father was acting in her best interest. Within the cultural context of kinship placement, family or clan discussions are usually held after such effectively planned fostering, as in the case of Eziuwa, goes wrong. There are also different types of fostering - kinship, educational, apprenticeship, and domestic (see Isiugo-Abanihe, 1985 for an exhaustive discussion). Trafficking and fostering though two different concepts are affected by the other. The manner in which children are circulated for kinship placement exposes children to exploitation (including sexual abuse and violence) by their supposed carers or extended family members and shifts the categorization of children's experiences from kinship fostering to trafficking (Ballet \& Bhukuth, 2016). The implication then is that the broad range of activities NAPTIP and the literature categorize as trafficking could actually be the effects of kinship fostering gone wrong. Since the researcher did not accompany NAPTIP on Eziuwa's family reunification process, the strained relationship that will exist between siblings (Eziuwa's father and his sister) on Eziuwa's return home can only be imagined.

Furthermore, within the age-old practice of kinship placement, when children were sent to live with trusted family members there were traditionally sanctioned ways for relatives to check on children's wellbeing (Rwezaura, 1998). In contemporary times, the community checks are thwarted by several factors - distance, the monetary cost of moving from rural to urban areas, the likely threat of road travelers by terrorists and Fulani herdsmen, deception in the course of children's movement from home, and excessive trust by parents. The absence of community checks explains why some children complained of extreme forms of mistreatment by their fostering families (parents and children), something those who grew up in the old traditional fostering system in West Africa was unlikely to experience. The researcher contends that though there may have been families that maltreated their fostered relatives within that era, the fear of being answerable to the immediate community and facing community sanctions guarded against high rates of discrimination or abuse by foster parents.

\section{CONCLUSION}

The study acknowledges that there are indicators that traditional child placement practices 
in Nigeria have transformed in the 21st century to become a new avenue for the exploitation of children, including those living with close relatives. The links to trafficking, notwithstanding, more research with affected children will enrich traditional child placement as an alternative to Eurocentric approaches for identifying and/or meeting children's needs within cultural expectations of the children's social, educational, religious, and spiritual development. Currently, children are removed from places where they are exposed to huge exploitation and risk and returned to homes that are unlikely to meet their needs for leaving home in the first instance. Moreover, if the underlying basis for children's placement in kinship care in the literature is poverty, which obscures the socialization component of the practice, then reintegration of affected children should dwell on policy-making that looks into the structural inequalities, which differ across gender divides, that is likely to push children away from their homes. The present study suggests that this input that effectively informs program decisions can only be achieved by recognizing the importance of children's voice in disclosing their reasons for leaving home within kinship placement, and their experiences and needs after removal from fostering families.

\section{REFERENCES}

Agblorti, S. \& Tanle, A. (2011). Child fostering and education in Ghana. SBHA,76(1), 53-70

Ainsworth, M. (1992). Economic aspects of child fostering in Cote d'Ivoire. Research in population economics, 8, 25-62

Ainsworth, M. Beegle, K., \& Koda, G. (2005). The impact of adult mortality and parental deaths on primary schooling in North-Western Tanzania. The Journal of Development Studies, 41(3), 412-439.

Ainsworth, M. \& Filmer, D. (2006). Inequalities in children's schooling: AIDS, orphanhood, poverty, and gender. World Development, 34(6), 1099-1128.

Akresh, R. (2009). Flexibility of household structure child fostering decisions in Burkina Faso. Journal of Human Resources, 44(4), 976-997.

Ballet, J. \& Bhukuth, A. (2016). Recruitment patterns of child trafficking in Madagascar:
An analysis based on missing and recovered children. Journal of Human Trafficking, 2(3), 235-254.

Bass, L. (2004). Child Labor in Sub-Saharan Africa. Boulder: Lynne Rienner Publishers.

Bledsoe, C. (1990). No Success without Struggle: Social Mobility and hardship for Foster Children in Sierra Leone. MAN, 25 (1), 70 88.

Bledsoe, C. \& Isiugo-Abanihe, U. (1989). Strategies of Child-Fosterage Among Mende Grannies in Sierra Leone, In R. Lesthaeghe. (Ed.), Reproduction and Social Organization in Sub-Saharan Africa, Berkeley, University of California Press.

Boyden, J. \& Mann, G. (2005). Children's Risk, Resilience and Coping in Extreme Situations, In M. Ungar. (Ed.), Pathways to Resilience, Thousand Oaks, Sage.

Boyden, J. \& Howard, N. (2013). Why does child trafficking policy need to be reformed? The moral economy of children's movement in Benin and Ethiopia. Children's Geographies, 11(3), 354-368.

Case, A., Paxson, C., \& Ableidinger, J. (2004). Orphans in Africa: Parental death, poverty, and school enrollment. Demography, 41(3), 483-508.

Davidson, J. (2011). Moving children? Child trafficking, child migration, and child rights. Critical Social Policy, 31(3), 454-477.

Desai, S. (1995). When are children from large families disadvantaged? Evidence from cross-national analyses. Population Studies, 49(2), 195-210.

Foster, G. (2000). The capacity for extended family safety net for orphans in Africa. Psychology, Health and Medicine, 5 (1), 55-62.

GoŹdziak, E. (2008). On Challenges, Dilemmas, and Opportunities in Studying Trafficked Children. Anthropological Quarterly, 81(4), $903-923$

Goody, E. (1982). Parenthood and Social Reproduction: Fostering and Occupational Roles in West Africa. Cambridge: Cambridge University Press.

Isiugo-Abanihe, U. (1985). Child fosterage in West Africa. Population and Development Review. 11(1), 53-73. 
Kuyini, A., Alhassan, A., Tollerud, I., Weld, H., \& Haruna, I. (2009). Traditional kinship foster care in northern Ghana: the experiences and views of children, carers and adults in Tamale. Child \& Family Social Work, 14(4), 440-449.

Mbakogu, I. (2004) Exploring the Forms of Child Abuse in Nigeria: Efforts at Seeking Appropriate Preventive Strategies. J. Soc. Sci, 8(1), 23 - 27.

Mbakogu, I. (2015) Understanding Child Trafficking From the Point of View of Trafficked Children: The Case of 'Rescued' Children in Nigeria (Unpublished Doctoral dissertation), McGill University, Montreal, Canada.

Mbakogu, I. (2016). Trafficking of Nigerian women and children: implications for attaining sustainable development in Nigeria. Yonsei Journal of International Studies. Migration \& Security. 8(1), 47 - 64

Mbakogu, I. (2020). Child Accusation of Witchcraft-Another Road into Trafficking. Journal of Social Work Education and Practice, 5(3), 17-33

Howard, N. (2011). Is 'child placement' trafficking?: Questioning the validity of an accepted discourse. Anthropology Today, 27(6), 3-7.

Manzo, K. (2005). Exploiting West Africa's children: trafficking, slavery and uneven development. Area, 37 (4), 393 - 401

Oluwaniyi, O. (2009). 'Internal Child Trafficking in Nigeria: Transcending Legal Borders', In O. Agbu. (Ed.), Children and Youth in the Labour Process in Africa. Dakar, Council for the Development of Social Science research in Africa (CODESRIA).

Phoenix, C. \& Smith, B. (2011). Telling a (Good?) Counterstory of Aging: Natural Bodybuilding Meets the Narrative of Decline. Sciences, 66 (5), 628-639.

Pilon, M. (2003). Foster Care and Schooling in West Africa: The State of Knowledge. Preparation of the UNESCO EFA Report.

Runyan, D. \& Gould, C. (1985). Foster care for child maltreatment: Impact on delinquent behavior. Pediatrics, 75(3), 562-568.

Rwezaura, B. (1998). Competing 'Images' of Childhood in the Social and Legal Systems of Contemporary Sub-Saharan Africa. International Journal of Law, Policy and the Family, 12(3), 253-278.

Serra, R. (2009). Child fostering in Africa: When labor and schooling motives may coexist. Journal of Development Economics, 88(1), $157-170$

UNICEF. (2002). Child Trafficking in West Africa: Policy Responses. Florence, UNICEF Innocenti Research Centre

Uzodike, E. (1990). Child abuse and neglect in Nigeria-socio-legal aspects. International Journal of Law, Policy and the Family, 4 (1), 83-96.

Zimmerman, F. (2003). Cinderella Goes to School the Effects of Child Fostering on School Enrollment in South Africa. Journal of Human Resources, 38(3), 557-590. 